\title{
PENGARUH TOURISM AMBASSADOR DAN RELIABILITY TERHADAP MINAT BERKUNJUNG DI OBJEK WISATA MUSEUM DELI SERDANG
}

\author{
Sabrimiralda Ulya ${ }^{1)} \&$ T. Teviana ${ }^{2)}$ \\ Fakultas Ekonomi, Universitas Negeri Medan \\ Fakultas Ekonomi, Universitas Negeri Medan \\ Email : ${ }^{1)}$ sabrimiraldaulya@gmail.com, ${ }^{2)}$ teviana3004@gmail.com
}

\begin{abstract}
Abstrak
Penelitian ini bertujuan untuk mengetahui pengaruh tourism ambassador dan reliability terhadap minat berkunjung di objek wisata Museum Deli Serdang. Penelitian ini menggunakan metode kuantitatif dengan teknik pengambilan sampel menggunakan teknik Simple random sampling, dengan jumlah sampel sebanyak 370 orang yang pernah berkunjung di Museum Deli Serdang. Teknik pengumpulan data dalam penelitian ini dilakukan dengan cara menyebarkan kuesioner yang pengukurannya dengan skala interval dan diolah secara statistik menggunakan analisis regresi linear berganda dan pengujian hipotesis dengan uji $\mathrm{F}$, uji $\mathrm{t}$ dan koefisien determinasi yang sebelumnya data telah diuji menggunakan uji validitas, uji reliabilitas dan uji asumsi klasik. Pengolahan data menggunakan program SPSS 21.0 for windows.

Secara parsial tourism ambassador dan reliability berpengaruh positif dan signifikan terhadap minat berkunjung pada Museum Deli Serdang. Berdasarkan hasil penelitian menunjukkan bahwa variabel tourism ambassador dan reliability secara simultan berpengaruh terhadap minat berkunjung. Hal ini terlihat dari nilai $F_{\text {hitung }}>F_{\text {tabel }}(394,043>3,02)$ dan nilai signifikannya $0,000<0,05$. Uji koefisien determinasi menunjukkan nilai sebesar 0,682 yang berarti bahwa tourism ambassador dan reliability berpengaruh terhadap minat berkunjung sebesar $68,2 \%$ sedangkan sisanya dipengaruhi oleh variabel lain.
\end{abstract}

Kata Kunci: tourism ambassador, reliability, minat berkunjung.

\section{Abstract}

This study aims to determine the effect of tourism ambassador and reliability on visiting interests in the Deli Serdang Museum attraction. This study uses quantitative methods with sampling techniques using simple random sampling technique, with a total sample of 370 people who have visited the Deli Serdang Museum. Data collection techniques in this study were carried out by distributing questionnaires whose measurement with interval scale and processed statistically using multiple linear regression analysis and hypothesis testing with the $F$ test, $t$ test and coefficient of determination before the data had been tested using validity test, reliability test and test classical assumption. Data processing using SPSS 21.0 for Windows.

Partially tourism ambassador and reliability have a positive and significant effect on the interest of visiting the Deli Serdang Museum. Based on the results of the study showed that the tourism ambassador and reliability variables simultaneously affect the interest in visiting. This can be seen from the value of $F_{\text {count }}>F_{\text {table }}$ $(394,043>3.02)$ and the significant value is $0,000<0.05$. The coefficient of determination test shows a value of 0.682 which means that tourism ambassador and reliability affect the interest in visiting by $68.2 \%$ while the rest is influenced by other variables.

Keywords: tourism ambassador, reliability, interest in visiting. 


\section{PENDAHULUAN}

Pariwisata adalah salah satu jenis industri baru yang mampu menghasilkan pertumbuhan ekonomi yang cepat dalam penyediaan lapangan kerja, peningkatan penghasilan, standar hidup serta menstimulasi sektor-sektor produktivitas lainnya. Selanjutnya sebagai sektor yang komplek juga meliputi industri-industri klasik yang sebenarnya seperti industri kerajinan dan cinderamata, penginapan dan transportasi, secara ekonomis juga dipandang sebagai industri. Pariwisata menjadi salah satu sumber devisa bagi negara-negara besar dan negara berkembang, termasuk di Indonesia sebagai sumber pemasukan langsung ke negara maupun langsung kepada masyarakat disekitar obyek wisata tersebut (Pendit, 2002).

Adapun wisata yang ada di Sumatera Utara yaitu wisata alam, wisata kuliner, wisata rekreasi, wisata sejarah dan religi, sanggar dan cagar budaya. Dengan adanya pariwisata, lebih dikhususkan untuk pemerintah daerah, objek wisata akan menjadi pemasukan bagi daerah itu sendiri. Salah satu objek wisata sejarah yang terdapat di daerah Deli Serdang yaitu Museum Deli Serdang. Museum Deli Serdang merupakan museum sejarah dan kebudayaan Deli Serdang yang terletak di Jl. Negara Lubuk Pakam. Museum Deli Serdang diresmikan oleh Menteri Pendidikan dan Kebudayaan Indonesia Prof. Dr. Muhajir Efendy, M.A.P., Gubernur Sumatera Utara Edy Rahmayadi, dan Bupati Deli Serdang H. Ashari Tambunan pada tanggal 8 September 2018.
Tabel 1 Data Kunjungan Museum Deli

Serdang

\begin{tabular}{|c|c|c|c|c|c|c|c|}
\hline \multirow{3}{*}{ No } & \multirow{3}{*}{ PENGUNJUNG } & \multicolumn{6}{|c|}{ BULAN } \\
\hline & & Juli & Agustus & September & Olitober & November & Desember \\
\hline & & 2019 & 2019 & 2019 & 2019 & 2019 & 2019 \\
\hline 1 & UNOM & 295 & 115 & 294 & 1277 & 1277 & 1074 \\
\hline 2 & TK/PAUD & & & 107 & 242 & 146 & 355 \\
\hline 3 & SD & 760 & 1810 & 1452 & 7934 & 6815 & 2639 \\
\hline 4 & SMPMNTS & 63 & 4 & & 496 & 482 & 799 \\
\hline 5 & SMA / SMR/ MAN & 70 & 300 & 2 & 65 & 421 & 26 \\
\hline 6 & GURU & & & & & & \\
\hline$?$ & UNIVERSITAS & 71 & 6 & 9 & 3 & 37 & 42 \\
\hline 8 & INSTANSI & 22 & 26 & & & & \\
\hline 9 & YAYASAN & & & & & & \\
\hline 10 & KESUL TANAN & & & & & & \\
\hline \multirow[t]{2}{*}{11} & MANCA NEGARA & & & & & 1 & 21 \\
\hline & JUMLAH & 1,281 & 2,261 & 1,864 & 10,017 & 9,179 & 4,956 \\
\hline \multicolumn{7}{|c|}{ TOTAL } & 29,558 \\
\hline
\end{tabular}

Sumber : Museum Deli Serdang 2019

Dari data diatas dapat kita lihat bahwa terdapat beragam jenis pengunjung pada Museum Deli Serdang, yaitu pengunjung umum, TK/PAUD, SD, SMP/MTs, SMA/SMK/MAN, Guru, Universitas, Instansi, Yayasan, Kesultanan dan Manca Negara yang mengalami perubahan jumlah pengunjung setiap bulannya. Jumlah pengunjung pada Museum Deli Serdang berfluktuasi setiap bulannya dilihat dari tipe pengunjung. Jika dilihat dari tabel, kenaikan jumlah pengunjung terjadi pada bulan Agustus, namun mengalami penurunan pada bulan September, kemudian meningkat lagi pada bulan Oktober, lalu mengalami penurunan pada bulan November dan mengalami penurunan lagi pada bulan Desember. Biasanya pemicu kenaikan jumlah pengunjung disebabkan oleh event-event besar seperti, peringatan Hari Museum Nasional, Festival Cagar Budaya dan musim libur anak sekolah. Dari data di atas dapat kita lihat bahwa tipe pengunjung yang memiliki jumlah 
kunjungan paling besar adalah siswa Sekolah Dasar.

Minat berkunjung wisatawan pada museum sangatlah kurang dikarenakan kurangnya rasa nasionalisme masyarakat, masyarakat lebih tertarik mengikuti perkembangan Iptek dibandingkan sejarah nasional Indonesia, masyarakat lebih tertarik untuk mengunjungi pusat perbelanjaan (mall) dan tempat hiburan dibanding museum, masyarakat kurang peduli dengan sejarah Indonesia dan banyak objek wisata lain yang bisa dikunjungi selain museum (Wibowo, 2015).

Dalam meningkatkan jumlah pengunjung pihak museum harus menjadikan masyarakat agar mempunyai minat berkunjung. Menurut Mauludin (2017) "minat berkunjung wisatawan merupakan suatu keinginan dimana seorang wisatawan tertarik untuk mengunjungi suatu daya tarik wisata". Minat berkunjung dipengaruhi oleh beberapa hal. Dalam penelitiannya menurut Sondakh (2016), menyatakan bahwa pelayanan, keamanan dan daya tarik berpengaruh secara simultan maupun parsial terhadap minat berkunjung wisatawan dan Raswendo (2018), dalam penelitiannya menyatakan bahwa kualitas pelayanan memiliki pengaruh signifikan terhadap minat pembelian ulang.

Salah satu cara yang dapat dilakukan dalam mempromosikan wisata agar meningkatkan minat berkunjung yaitu melalui duta wisata (Tourism Ambassador). Duta wisata sendiri merupakan putra/putri terbaik daerah yang dijadikan contoh oleh muda/mudi yang mempunyai intelektualitas yang baik maupun penampilan yang menarik ke masyarakat dengan kerapian, kebersihan serta senyum dalam komunikasi yang memberikan kesan baik kepada masyarakat, serta kepribadian yang baik dan memiliki kemampuan menguasai kebudayaan yang ada di daerah tersebut. Duta wisata yang diharapkan dapat mewakili daerahnya dalam upaya mempromosikan potensi dan aset wisata daerahnya, juga diharapkan bagi yang terpilih menjadi duta wisata adalah sosok duta wisata yang kreatif, inovatif, percaya diri, berpengalaman dan berjati diri (Randa, 2015).

Tourism ambassador Deli Serdang merupakan ikon pariwisata dan kebudayaan yang ada di daerah tersebut. Tugas utama tourism ambassador adalah memajukan serta mempromosikan pariwisata yang ada di Deli Serdang. Dikarenakan kita memasuki era Revolusi Industri 4.0 jadi hal yang dilakukan tourism ambassador dalam mempromosikan pariwisata di Deli Serdang yaitu dengan cara aktif mempromosikan pariwisata melalui media sosial seperti Instagram, Youtube, Facebook dan WhatsApp, membagikan brosur pariwisata secara online dan offline ke masyarakat umum, terjun langsung ke tempat wisata itu sendiri, ikut serta dalam setiap event-event yang berhubungan langsung dengan pariwisata di Deli Serdang.

Dengan adanya tourism ambassador Deli Serdang para pengunjung akan mendapatkan informasi yang menarik dan akurat. Tugas tourism ambassador di Museum Deli Serdang adalah mempromosikan Museum 
Deli Serdang kepada masyarakat baik masyarakat lokal maupun mancanegara. Selain itu tugas tourism ambassador Deli Serdang adalah memandu wisatawan selama perjalanan wisata sehingga para pengujung akan mengetahui rute jalan saat berada di Museum Deli Serdang, memberikan penjelasan dengan sebaik-baiknya mengenai koleksi-koleksi yang ada di Museum Deli Serdang dan berswafoto bersama wisatawan yang ada di Museum Deli Serdang. Tourism ambassador aktif dalam mempromosikan pariwisata melalui media sosial, namun pelaksanaan promosi khususnya di tempat wisata Museum Deli Serdang tidak dilakukan secara berkala.

Selain tourism ambassador yang dapat meningkatkan minat berkunjung adalah kualitas pelayanan. Salah satu indikator dari kualitas pelayanan adalah reliability. Reliability merupakan salah satu indikator dari kualitas pelayanan. Menurut Kotler (2002) reliability adalah "kemampuan untuk melaksanakan jasa yang dijanjikan secara terpercaya dan akurat. Kinerja harus sesuai dengan harapan yang berarti ketepatan waktu, pelayanan yang sama untuk semua pelanggan tanpa kesalahan, sikap simpatik, dan dengan akurasi yang tinggi”.

\section{Reliability yang terdapat dalam} penelitian ini adalah pihak museum memberikan informasi yang terpercaya. Salah satu nya yaitu Museum Deli Serdang telah meresmikan aplikasi Guide Museum Daerah Deli Serdang, dengan adanya aplikasi tersebut dapat mempermudah pengujung mengetahui rute jalan saat berada di Museum. Selain itu pihak Museum Deli Serdang juga membuat Program BBM (Belajar Bersama di Museum) yang dipromosikan dengan ilustrasi komik yang menarik. Dengan adanya program ini dapat menumbuhkan rasa penasaran sehingga masyarakat memiliki minat untuk berkunjung di Museum. Sedangkan proses administrasi di Museum Deli Serdang yang masih dilakukan secara konvensional. Salah satu nya yaitu ketika wisatawan berkunjung, daftar buku tamu masih ditulis secara manual.

\section{TINJAUAN PUSTAKA}

\section{Minat Berkunjung}

Menurut Mauludin (2017) "Minat berkunjung wisatawan merupakan suatu keinginan dimana seorang wisatawan tertarik untuk mengunjungi suatu daya tarik wisata”.

Menurut Albarg (2014: 14) yang menyamakan bahwa minat berkunjung wisatawan sama dengan minat pembelian konsumen.

Menurut Durianto (2013 : 58) "Minat beli adalah keinginan untuk membeli produk , minat beli akan timbul apabila seseorang konsumen sudah terpengaruh terhadap mutu dan kualitas dari mutu produk, informasi seputar produk, cara membeli dan kemewahan serta keunggulan produk dibidang merek lain".

\section{Tourism Ambassador (Duta Wisata)}

Menurut Satriawan (2013: 39) "Duta wisata adalah ikon atau figur pariwisata dan kebudayaan yang terpilih setelah melewati serangkaian proses seleksi yang dalam bentuk pemilihan yang diikuti oleh generasi muda atau remaja”. Menurut Satriawan (2013: 40) 
Duta wisata merupakan perpanjangan tangan pemerintah dalam upaya memperkenalkan potensi pariwisata dengan tujuan dapat meningkatkan kunjungan wisatawan baik lokal maupun asing.

Menurut Andriyani (2014: 162) "Duta wisata merupakan putra-putri yang mewakili daerahnya dalam upaya mempromosikan potensi dan aset wisata daerahnya, diharapkan dengan menyandang gelar sebagai duta wisata mereka yang terpilih adalah sosok duta wisata yang kreatif, inovatif, percaya diri, berpengalaman dan berjati diri”.

\section{Reliability (Kehandalan)}

Menurut Kotler (2002) "Kehandalan adalah kemampuan untuk melaksanakan jasa yang dijanjikan secara terpercaya dan akurat. Kinerja harus sesuai dengan harapan yang berarti ketepatan waktu, pelayanan yang sama untuk semua pelanggan tanpa kesalahan, sikap simpatik, dan dengan akurasi yang tinggi”.

Menurut Zeithaml, dkk (dalam Hadani 2008) keandalan (reliability), yakni kemampuan memberikan pelayan yang dijanjikan dengan segera, akurat dan memuaskan serta sesuai dengan yang telah dijanjikan.

Reliability (keandalan), yaitu kemampuan karyawan di objek wisata untuk memberikan pelayanan sesuai dengan janji yang diberikan kepada pengunjung secara akurat dan terpercaya (Batista et al, 2014).

\section{Hipotesis}

H1 : Tourism Ambassador berpengaruh terhadap minat berkunjung di objek wisata Museum Deli Serdang.

H2 : Reliability berpengaruh terhadap minat berkunjung di objek wisata Museum Deli Serdang.

H3 : Tourism Ambassador dan Reliability berpengaruh terhadap minat berkunjung di objek wisata Museum Deli Serdang.

\section{METODE PENELITIAN}

Populasi adalah kelompok element yang lengkap, yang biasanya berupa orang, objek, transaksi atau kejadian dimana kita tertarik untuk mampelajari atau menjadi objek penelitian (Kuncoro, 2013). Populasi dalam penelitian ini adalah seluruh pengunjung yang ada di Museum Deli Serdang pada bulan 12 tahun 2019 yang berjumlah 4.956 orang, sumber data tersebut dapat dilihat pada pendahuluan tabel 1 halaman 2 .

Menurut Sugiyono (2012) sampel adalah sebagian dari populasi itu. Sampel merupakan suatu cara dalam pengumpulan data yang sifatnya tidak menyeluruh, akan tetapi sebagian saja dari populasi. Teknik pengambilan sampel menggunakan rumus Taro Yamane atau Slovin, adalah sebagai berikut :

$$
n=\frac{\mathrm{N}}{\mathrm{N} \cdot d^{2}+1}
$$

Dimana : $n=$ Jumlah sampel

$$
\mathrm{N} \text { = Jumlah popolasi }
$$

$\mathrm{d}=$ Presisi (ditetapkan dengan tingkat kesalahan 5\%) 
Berdasarkan rumus tersebut, maka jumlah sampel yang digunakan dalam penelitian ini adalah :

$$
\begin{aligned}
n & =\frac{4.956}{4.956(0,05)^{2}+1} \\
& =\frac{4.956}{13,39} \\
& =370
\end{aligned}
$$

Berdasarkan perhitungan diatas, maka jumlah sampel yang digunakan dalam penelitian ini adalah sebanyak 370 orang responden dengan taraf kesalahan 5\%. Responden disusun dengan menggunakan simple random sampling (sampel random sederhana). Sampel yang diambil dalam penelitian ini adalah 370 orang yang menjadi wisatawan di Museum Deli Serdang.

Teknik pengumpulan data yang digunakan dalam penelitian ini yaitu observasi, wawancara, studi kepustakaan dan kuesioner.

\section{HASIL DAN PEMBAHASAN}

\section{Hasil Penelitian}

Berdasarkan hasil pengolahan data dalam penelitian dapat diperoleh persamaan regresi linear berganda sebagai berikut:

$$
\mathrm{Y}=\mathbf{2 , 9 1 2}+\mathbf{0 , 2 0 2} \mathrm{X}_{1}+\mathbf{0 , 4 5 6} \mathrm{X}_{2}+\mathrm{e}
$$

Yang berarti:

- Nilai konstanta Minat Berkunjung (Y) sebesar 2,912 yang menyatakan jika tidak ada variabel X, yaitu Tourism Ambassador dan Reliability maka Minat Berkunjung adalah 2,912 dengan asumsi faktor lain konstan.

- Koefisien $X_{1}$ sebesar 0,202 menyatakan bahwa setiap terjadi peningkatan Tourism
Ambassador mempengaruhi Minat Berkunjung sebesar 0,202 dengan asumsi faktor lain konstan.

- Koefisien $\mathrm{X}_{2}$ sebesar 0,456 menyatakan bahwa setiap terjadi peningkatan Reliability mempengaruhi Minat Berkunjung sebesar 0,456 dengan asumsi faktor lain konstan.

Selain itu diperoleh juga hasil uji t dari pengolahan data adalah sebagai berikut:

- Variabel Tourism Ambassador memiliki $t_{\text {hitung }}>\mathrm{t}_{\text {tabel }}$ yaitu $6,028>1,966449$ dan taraf signifikansinya sebesar $0,000<0,05$. Hal tersebut berarti secara parsial dan secara signifikan Tourism Ambassador berpengaruh positif terhadap Minat Berkunjung. Berdasarkan hasil tersebut maka Ho ditolak dan Ha diterima.

- Variabel Reliability memiliki $\mathrm{t}_{\text {hitung }}>\mathrm{t}_{\text {tabel }}$ yaitu $13,743>1,966449$ dan taraf signifikansi sebesar $0,000<0,05$. Hal tersebut berarti secara parsial dan secara signifikan Reliability berpengaruh positif terhadap Minat Berkunjung. Berdasarkan hasil tersebut maka Ho ditolak dan $\mathrm{Ha}$ diterima.

Dan uji f yaitu uji secara simultan diperoleh nilai $F_{\text {hitung }}$ sebesar 394.043 lebih besar daripada $F_{\text {tabel }}$ sebesar 3,02 dan dengan tingkat signifikansi $0,000<0,05$. Karena $F_{\text {hitung }}$ $>\mathrm{F}_{\text {tabel }}$ yang berarti bahwa Ho ditolak dan $\mathrm{Ha}$ diterima, sehingga dapat disimpulkan bahwa Tourism Ambassador dan Reliability berpengaruh secara simultan (bersama-sama) terhadap Minat Berkunjung pada Museum Deli Serdang. 
Hasil uji koefisien determinasi diketahui bahwa besarnya angka R2 adalah 0,682 yang menunjukkan bahwa variabel independen yaitu Tourism Ambassador $\left(\mathrm{X}_{1}\right)$ dan Reliability $\left(\mathrm{X}_{2}\right)$ menjelaskan pengaruh terhadap variabel dependen yaitu Minat Berkunjung (Y) sebesar 0,682 atau 68,2\% sedangkan sisanya $31,8 \%$ dipengaruhi oleh faktor-faktor lainnya yang berasal dari luar variabel yang diteliti.

\section{Pembahasan Hasil Penelitian}

Penelitian ini bertujuan untuk mengetahui pengaruh Tourism Ambassador $\left(\mathrm{X}_{1}\right)$ dan Reliability $\left(\mathrm{X}_{2}\right)$ terhadap Minat Berkunjung (Y) pada Museum Deli Serdang. Data dalam penelitian ini diambil dengan cara menyebar kuesioner kepada wisatawan yang pernah berkunjung di Museum Deli Serdang. Teknik analisis data yang digunakan adalah regresi linear berganda dengan bantuan program SPSS 21.0 for windows.

Menurut Satriawan (2013) duta wisata merupakan perpanjangan tangan pemerintah dalam upaya memperkenalkan potensi pariwisata dengan tujuan dapat meningkatkan kunjungan wisatawan baik lokal maupun asing. Oleh karena itu dengan adanya brain, behavior dan beauty dari seorang duta wisata dapat menarik wisatawan untuk mengunjungi daya tarik wisata. Hasil penelitian yang dilakukan menunjukan bahwa variabel Tourism Ambassador memiliki $\mathrm{t}_{\text {hitung }}>\mathrm{t}_{\text {tabel }}$ yaitu $6,028>1,966449$ dan taraf signifikansinya sebesar $0,000<0,05$. Hasil penelitian yang dilakukan menunjukkan bahwa Tourism Ambassador berpengaruh positif dan signifikan terhadap Minat Berkunjung. Sehingga dapat disimpulkan hipotesis pertama dapat diterima.

Menurut Batista et al (2014) reliability (keandalan) yaitu kemampuan karyawan di objek wisata untuk memberikan pelayanan sesuai dengan janji yang diberikan kepada pengunjung secara akurat dan terpercaya. Keahlian pegawai dengan menggunakan alat bantu dalam pelayanan dan memberikan informasi secara terpercaya dapat meningkatkan minat wisatawan dalam berkunjung di suatu objek wisata.

Hasil penelitian yang dilakukan menunjukan bahwa variabel Reliability memiliki $t_{\text {hitung }}>\mathrm{t}_{\text {tabel }}$ yaitu $13,743>1,966449$ dan taraf signifikansi sebesar $0,000<0,05$. Hal tersebut berarti secara parsial dan secara signifikan Reliability berpengaruh positif terhadap Minat Berkunjung. Hal ini sejalan dengan penelitian Sondakh (2016), menyatakan bahwa pelayanan, keamanan dan daya tarik berpengaruh secara simultan maupun parsial terhadap minat berkunjung wisatawan.

Selain uji $\mathrm{t}$, peneliti juga melakukan uji $\mathrm{F}$ (signifikan simultan). Setelah mendapatkan hasil uji $\mathrm{F}$, peneliti membandingkan hasil hitung uji $F_{\text {hitung }}$ dengan $F_{\text {tabel }}$ yang hasilnya $\mathrm{F}_{\text {hitung }}>\mathrm{F}_{\text {tabel. }}$. Dengan demikian, dapat ditarik kesimpulan bahwa Tourism Ambassador dan Reliability berpengaruh positif dan signifikan terhadap Minat Berkunjung. Sehingga penelitian ini menyatakan bahwa secara simultan Tourism Ambassador dan Reliability bersama-sama berpengaruh positif terhadap 
Minat Berkunjung pada Museum Deli Serdang. Hasil uji adjusted $\mathrm{R}^{2}$ pada penelitian ini diperoleh sebesar 0,682. Hal itu menunjukkan bahwa besarnya pengaruh Tourism Ambassador dan Reliability terhadap Minat Berkunjung adalah sebesar 68,2\% sedangkan $31,8 \%$ sisanya dipengaruhi oleh faktor lainnya yang berasal dari variabel lainnya. Dari hal di atas, dapat dilihat bahwa Tourism Ambassador dan Reliability mempengaruhi Minat Berkunjung dan hasil tersebut menjadi pertimbangan bagi wisatawan sebelum berkunjung di Museum Deli Serdang.

\section{KESIMPULAN DAN SARAN}

Berdasarkan pembahasan di atas maka dapat ditarik kesimpulan bahwa (1) Tourism Ambassador berpengaruh positif terhadap Minat Berkunjung pada Museum Deli Serdang, telah diuji dan terbukti dapat diterima kebenarannya. Dengan demikian hipotesis pertama diterima. (2) Reliability berpengaruh positif terhadap Minat Berkunjung pada Museum Deli Serdang. Hal ini menyatakan hipotesis yang dirumuskan peneliti yaitu Reliability diduga berpengaruh positif terhadap Minat Berkunjung, telah diuji dan terbukti dapat diterima kebenarannya. Dengan demikian hipotesis kedua diterima. (3) Setelah penulis melakukan penelitian mengenai Pengaruh Tourism Ambassador dan Reliability terhadap Minat Berkunjung pada Museum Deli Serdang, maka dapat disimpulkan bahwa Tourism Ambassador dan Reliability secara bersama-sama (simultan) berpengaruh terhadap Minat Berkunjung. Dengan demikian hipotesis ketiga diterima.

Berdasarkan kesimpulan diatas maka saran penelitian ini adalah :

(1) Variabel tourism ambassador memiliki pengaruh yang positif dan signifikan terhadap Minat Berkunjung, tourism ambassador sebagai komunikator harus memiliki ethos atau credibility (ahli dan dapat dipercaya), memiliki daya tarik (attractiveness) dan kekuasaan (power). Serta diharapkan mampu bekerjasama dengan pemerintah atau dinas terkait. Perlu adanya kerjasama yang baik antara Pemerintah dan Duta Wisata Deli Serdang dalam hal ini perlu menyusun dan merancang program promosi pariwisata secara bersama-sama dan sebaiknya menggunakan strategi Bauran Komunikasi. Serta Pemerintah perlu menganggarkan dana untuk program promosi tentang potensi wisata Kabupaten Deli Serdang yang dijalankan oleh Duta Wisata. Sehingga Duta Wisata Deli Serdang dapat secara maksimal menjalankan peran mereka sebagai Duta Pariwisata membantu pemerintah memperkenalkan atau mempromosikan Potensi wisata Kabupaten Deli Serdang khususnya pada objek wisata Museum Deli Serdang. (2) Sementara untuk variabel reliability, perlu diperhatikan peningkatan kualitas pelayanan oleh pegawai museum seperti administrasi museum lebih di upgrade lagi, dengan perkembangan teknologi yang semakin canggih sebaiknya pelaksanaan administrasi pencatatan buku tamu dilakukan menggunakan komputer. (3) Kabupaten Deli Serdang memiliki kekayaan alam yang sungguh 
berpotensi untuk dikembangkan. Untuk itu, Pemerintah perlu membenahi atau menata objek-objek wisata yang ada di Kabupaten Deli Serdang secara terus menerus dan memperbaiki sarana-prasarana ataupun segala vasilitas yang ada serta mengeksplor kekayaan wisata Kabupaten Deli Serdang ke berbagai daerah di Indonesia ataupun luar negeri dengan memanfaatkan berbagai media. Sehingga pengetahuan khalayak baik yang berada didalam negeri maupun luar negeri tentang Kabupaten Deli Serdang akan semakin meningkat. Sehingga hal ini diharapkan dapat juga berdampak baik terhadap jumlah kunjungan wisatawan di Kabupaten Deli Serdang yang semakin meningkat maupun pertumbuhan perekonomian daerah.

(4) Kepada peneliti selanjutnya, karena penelitian ini mengangkat pengaruh tourism ambassador dan reliability yang memiliki nilai $\mathrm{R}$ Square tinggi yaitu $68,2 \%$ dan sisanya $31,8 \%$ merupakan faktor lainnya diluar variabel yang diteliti dalam penelitian ini. Maka peneliti menyarankan adanya penelititan lebih lanjut dan lebih mendalam dengan menambahkan atau mengganti variabel bebas terhadap Minat Berkunjung seperti tangible, responsiveness, empathy, assurance dan dimensi kualitas pelayanan yang lainnya.

\section{REFERENSI}

Albarq, Abbas N. 2014. Measuring the Impacts of Online Word of Mouth on Tourists' Attitude and Intentions to Visit Jordan: An Empirical Study. International Business Research; Vol. 7,No.1.
Batista, M., Couto, J.P., Botelho, D., and Faias, C., 2014. Tourist satisfaction and loyalty in the hotel business: An application to the island of São Miguel, Azores. Tourism \& Management Studies, 10 (1) : 16-23.

Durianto, Darmadi 2013. Strategi Menaklukan Pasar Melalui Riset Ekuitas dan Perilaku Merek (cet. ke-10). Jakarta: PT Gramedia Pustaka Utama.

Hadani. 2008. Analisis Pengaruh Kualitas Layanan Terhadap Minat Beli Ulang (Studi Empiris Pada Pt. Sriwijaya Air Distrik Semarang). Jurnal Bisnis Strategi. vol/17.no/22.

Kotler, Philip. 2002. Manajemen Pemasaran. Jilid 1\&2. Edisi Milenium. Jakarta: Prehalindo.

Kuncoro, M. 2013. Metode Riset untuk Bisnis dan Ekonomi Edisi 4. Jakarta : Erlangga.

Mauludin. 2017. Pengaruh Atraksi Wisata Terhadap Minat Berkunjung Wisatawan ke Daya Tarik Wisata Waduk Darma Kabupaten Kuningan. Jurnal Manajemen Resort dan Leisure. Vol.14/no.2/oktober/2017. Fakultas Pendidikan dan Ilmu Pengetahuan Sosial Universitas Pendidikan Indonesia.

Nuraeni, B.S. 2014. Analisis Faktor-faktor yang Mempengaruhi Minat Kunjung Ulang Wisatawan Museum Ranggawarsita Semarang. Jurnal Bisnis Strategi. 23 (1): 1-20.

Pendit, N.S 2002, Ilmu Pariwisata, PT. Pradnya Paramita, Jakarta. 
Randa. 2015. Peran Duta Wisata Dalam Mempromosikan Pariwisata Kabupaten Solok. Jurnal FISIP. vol/2.no/2.

Raswendo.2018. Pengaruh Kualitas Pelayanan Memberikan Pengaruh Positif Yang Signifikan Terhadap Minat Beli Ulang Dari Konsumen PT. Sriwijaya Air. Fakultas Ekonomi dan Bisnis Islam UIN Raden Intan Lampung. Lampung.

Satriawan, 2013, Hakikat Pemilihan Duta Wisata, Cendana Offset, Surakarta.

Sondakh, Tumbel. 2016. Pelayanan, Keamanan Dan Daya Tarik Mempengaruhi Minat Wisatawan Yang Berkunjung Ke Objek Wisata Alam Gunung Mahawu, Tomohon. Jurnal Berkala Ilmiah Efisiensi. Vol/16.no/1.

Sugiyono. 2012. Metode Penelitian Kuantitatif

Kualitatif dan $R \& D$. Bandung: Alfabeta.

Wibowo, A.J.I. 2015. Persepsi Kualitas

Layanan Museum di Indonesia: Sebuah Studi Observasi. Jurnal Manajemen, Vol.15, No.1.

\section{Website}

Andriyani, Leliyana. Jenis Promosi.

http://www.ejournal.ilkom.fisip-

unmul.ac.id [20 Desember 2019]. 